\title{
Assessment of Food Security among Farm Women - A Case Study of Mirzapur District in Uttar Pradesh, India
}

\author{
Dinesh", H. P. Singh and Gyanaprakash Bishi \\ Department of Agricultural Economics, Institute of Agricultural Sciences, \\ Banaras Hindu University, Varanasi, Uttar Pradesh \\ *Corresponding author
}

\section{Keywords}

Body Mass Index, Food Security,

Farm women,

Household Food

Article Info

Accepted:

05 February 2020

Available Online:

10 March 2020

\section{A B S T R A C T}

India is an agrarian economy, where women comprise a large part of the total workforce. The agriculture sector employs $80 \%$ of all active women in India, women comprise $33 \%$ of the agricultural labour force (Oxford Committee for Famine Relief, 2018). A nation with such a large workforce is still deprived of food security, which makes it a matter of utmost concern. A study was conducted in the Mirzapur district of Uttar Pradesh to analyze the food security status among farm women. The study reveals that $78 \%$ of the sample population belongs to the food insecure category. Majority of farm women nearly $45 \%$ respondent belongs to moderate food insecurity. About $90.91 \%$ of marginal farm women are food insecure. Age showed a negative relation with BMI whereas the other factors such as land, education, expenditure on food per person per month, agricultural and non-agricultural income showed a positive relationship with BMI. However, land-holding and education resulted to be non-significant factors while the rest factors were significant. $78.3 \%$ of the variations in BMI was observed due to the above-mentioned factors.

\section{Introduction}

"Hunger is not an issue of charity, it is an issue of justice", a well said line depicting global food security. India is the leading producer and exporter in agricultural and allied commodities at a global level, bringing in the name of an agrarian nation. But such glorious records fail to hide the pathetic situation of Indian farmers especially the women farmers. The green revolution was able to increase productivity leading to manifold increase in production and thus, transforming the nation from food deficient nation to a food self- sufficient country. The surplus stock till date is unable to feed million mouths properly together, which is depicted from the high malnutrition rates. As indicated 
by United Nations-India, 17 percent of the total population and 14.8 percent of the world's undernourished population, India bears a colossal weight of food and nutrition insecurity (more than 195.8 million people), around 43 percent children in India are constantly undernourished.

India positions 100 out of 119 nations in the Global Hunger Index 2017 and ranked $76^{\text {th }}$ in Food Security Index2018. This highlights the need for food security to provide each countryman with their basic right to food. Food security is one of the prime agenda of United Nations Sustainable Development Goals as the second SDG pledges to end hunger, achieve food security, improve nutrition and promote sustainable agriculture.

Food security is defined as a condition that exists when "all people, at all times have physical and economic access to sufficient, safe and nutritious food that meets their dietary needs and food preferences for an active and healthy life" (FAO World Food Summit,1996). Thus, the three pillars of food security are aggregate food availability, household food access and, individual food utilization. The food security scenario in case of rural poor in India is worst, as the average per capita consumption of energy in the rural area is $1811 \mathrm{kcal} /$ day (Food and Nutrition Security Analysis, 2019), which is far below than the recommended intake of 2,155 $\mathrm{kcal} /$ day as per ICMR norms. Women's nutrition is a matter of utmost priority as a third of Indian women of reproductive age is undernourished with a body mass index (BMI) of less than $18.5 \mathrm{~kg} / \mathrm{m}^{2}$ (UNICEF India). Women as farmers, labourers and entrepreneurs are the significant driving force of India's agriculture. According to OXFAM (Oxford Committee for Famine Relief, 2018) agriculture sector employs 80 percent of all active women in India, women comprise 33 percent of the agriculture labour force and 48 percent of the self-employed farmers.

Despite, their large contribution towards the rural economy of India the food security status of farm women is still a less dealt aspect. This paper is aimed to examine the food security status among farm women in the Mirzapur district of Uttar Pradesh, it will also assess the relative contribution of the independent factors on Body Mass Index (BMI) of farm women of the above study area.

\section{Materials and Methods}

\section{Collection of data}

The study concentrates on Mirzapur district located in eastern Uttar Pradesh. The reason for the selection of this district is it is counted among the backward districts of the state, as per the record of the Ministry of Panchayati Raj. It is also characterized as a low food availability district with moderate food insecurity.

There are 12 blocks in Mirzapur district, out of which two blocks viz; Jamalpur and Narayanpur were selected purposively because from the past many years' several programs/training had been organized in these two blocks for the development and upliftment of the farmers. From Jamalpur block, Pirkhir village was selected and Kailahat village from Narayanpurblock was selected purposively.

From these two selected villages, a list of farm women was prepared to have the characteristics of being married, 35yrs and above in age and engaged in agricultural activities. From this list, 100 respondents were randomly selected. Out of these 100 respondents 22 farm women were marginal farmers, 43 were small farmers and 35 farm women belonged to medium farmers category. 
Analytical techniques employed for analyzing the data

\section{Food security status of farm women}

To fulfil the above-stated objective of analysis of the food security status of farm women, Household Food Insecurity Assessment Scale (FAO, 2013) was used. The schedule consisted of nine questions related to criteria such as accessibility, quality, preferences and availability etc.

Score zero was allotted for the respondents who answered 'No' to the question and if the answer was 'Yes' then there were scored on a three-pointer scale i.e. rarely (score1), sometimes (score 2) and often (score 3).The procedure used to classify the farm women in different food insecurity category is given in Table-1.

Assessment of the relative contribution of different factors on body mass index (BMI)

The anthropometric data (including height and weight only) was further used for computing BMI. The Body Mass Index is a recent valid index of nourishment status, that is calculated to know the relationship of different factors like agricultural income, nonagricultural income, education, age, landholding with BMI.

The BMI calculated by the formula:

$$
\text { BMI }=\frac{\text { Weight }(\mathrm{kg} .)}{\left(\text { Height }^{*}\right)^{2}}
$$

\section{(*Height in meters)}

Multiple linear regression model is used to get relationship between BMI and other factors under consideration and the equation is given below:

$\mathbf{Y}=\mathbf{b}_{0}+\mathbf{b}_{1} \mathbf{X}_{1}+\mathbf{b}_{2} \mathbf{X}_{2}+\mathbf{b}_{3} \mathbf{X}_{3}+\mathbf{b}_{4} \mathbf{X}_{4}+\mathbf{b}_{5} X_{5}+\mathbf{b}_{6} X_{6}+\mathbf{U}_{\mathrm{i}}$
$\mathrm{Y}=$ Body Mass Index $(\mathrm{kg} / \mathrm{m} 2)$

$\mathrm{b}_{0}=$ Intercept

$\mathrm{X}_{1}=$ Education (in term of years of schooling)

$\mathrm{X}_{2}=$ Age (in years)

$\mathrm{X}_{3}=$ Expense on food per month per person (in rupees)

$\mathrm{X}_{4}=$ Agricultural Income (in rupees)

$\mathrm{X}_{5}=$ Non-agricultural Income (in rupees)

$\mathrm{X}_{6}=$ Landholding (in acres)

$\mathrm{U}_{\mathrm{i}}=$ Error term

$\mathrm{b}_{1}, \mathrm{~b}_{2}, \mathrm{~b}_{3}, \mathrm{~b}_{4}, \mathrm{~b}_{5}, \mathrm{~b}_{6}=$ The regression coefficient of their respective independent variables.

\section{Results and Discussion}

Food security status among farm women

Frequency distribution of the total sample in food secure and insecure category

Table-2 depicts the distribution of farm women in food secure and insecure categories. It was observed that 78 percent of the sample farm women were under insecure food category of various degrees of insecurity, while the rest 22 percent of the sample belonged to the secure food category.

Further, it was observed that 90.91 percent of the farm women were from marginal farmer's households that fell under the insecure food category followed by small (86.04\%) and medium farmers $(60 \%)$. Regarding the food security status of the sample, it was concluded that the highest percent of food secure farm women were medium farmers followed by small (13.96\%) and marginal (9.09\%) farmers respectively.

Frequency distribution of the total sample according to food insecurity status

Food security is the major concern of study Table-3 shows the frequency distribution of 
farm women among different food insecurity status categories. A majority of farm women belong to moderate food insecurity status $(45 \%)$ followed by mild food insecure (26\%), and severe food insecure (7\%) status respectively.

Frequency distribution of farm women in different categories based on food security and insecurity status along with scale

Table-4 shows the food security and insecurity status of farm women in different categories. Out of the 100 farm women considered for the study, majority of them fell in scale3i.e.moderate food insecure category which accounts for about 45 percent of the total, followed by 26 percent in mild food insecure category and 22 percent in food secure category. The maximum $(63.63 \%)$ percentage of farm women having access to secure food belongs to medium farmers' category.

\section{Relative contribution of independent factors on body mass index (BMI)}

In this section, the contribution of age, education, landholding, and expenditure on food per person per month, agricultural and non-agricultural in come on BMI was assessed with the help of linear regression model.

\section{Table.1 Procedure used to classify farm women in different food security and insecurity category}

\section{Calculate the Household Food Insecurity Assessment (HFIA) category for each household.}

1 = Food Secure, 2=Mildly Food Insecure Access, 3=Moderately Food Insecure Access, 4=Severely Food Insecure Access

HFIA category $=1$ if $[(\mathrm{Q} 1 \mathrm{a}=0$ or $\mathrm{Q} 1 \mathrm{a}=1)$ and $\mathrm{Q} 2=0$ and $\mathrm{Q} 3=0$ and $\mathrm{Q} 4=0$ and $\mathrm{Q} 5=0$ and $\mathrm{Q} 6=0$ and $\mathrm{Q} 7=0$ and $\mathrm{Q} 8=0$ and $\mathrm{Q} 9=0]$

HFIA category $=2$ if $[(\mathrm{Q} 1 \mathrm{a}=2$ or $\mathrm{Q} 1 \mathrm{a}=3$ or $\mathrm{Q} 2 \mathrm{a}=1$ orQ2 $\mathrm{a}=2$ or $\mathrm{Q} 2 \mathrm{a}=3$ or $\mathrm{Q} 3 \mathrm{a}=1$ or $\mathrm{Q} 4 \mathrm{a}=1)$ and $\mathrm{Q} 5=0$ and $\mathrm{Q} 6=0$ and $\mathrm{Q} 7=0$ and $\mathrm{Q} 8=0$ and $\mathrm{Q} 9=0]$

HFIA category $=3$ if $[(\mathrm{Q} 3 \mathrm{a}=2$ or $\mathrm{Q} 3 \mathrm{a}=3$ or $\mathrm{Q} 4 \mathrm{a}=2$ orQ4 $\mathrm{a}=3$ or $\mathrm{Q} 5 \mathrm{a}=1$ or $\mathrm{Q} 5 \mathrm{a}=2$ or $\mathrm{Q} 6 \mathrm{a}=1$ or $\mathrm{Q} 6 \mathrm{a}=2$ ) and $\mathrm{Q} 7=0$ and $\mathrm{Q} 8=0$ and $\mathrm{Q} 9=0$ ]

HFIA category $=4$ if $[\mathrm{Q} 5 \mathrm{a}=3$ or $\mathrm{Q} 6 \mathrm{a}=3$ or $\mathrm{Q} 7 \mathrm{a}=1$ or $\mathrm{Q} 7 \mathrm{a}=2$ or $\mathrm{Q} 7 \mathrm{a}=3$ or $\mathrm{Q} 8 \mathrm{a}=1$ or $\mathrm{Q} 8 \mathrm{a}=2$ or $\mathrm{Q} 8 \mathrm{a}=3$ or $\mathrm{Q} 9 \mathrm{a}=1$ or $\mathrm{Q} 9 \mathrm{a}=2$ or $\mathrm{Q} 9 \mathrm{a}=3$ ]

(Source: Food and Agriculture Organisation, 2013)

Table.2 Frequency distribution of farm women in food secure and insecure category

\begin{tabular}{|c|c|c|c|}
\hline Category & Food secure & Food Insecure & Total \\
\hline Marginal & $2(\mathbf{9 . 0 9})$ & $20(90.91)$ & 22 \\
\hline Small & $\mathbf{6}(\mathbf{1 3 . 9 6})$ & $37(\mathbf{8 6 . 0 4})$ & 43 \\
\hline edium & $14(\mathbf{4 0 . 0 0 )}$ & $21(\mathbf{6 0 . 0 0})$ & 35 \\
\hline Total & $\mathbf{2 2}(\mathbf{2 2 . 0 0 )}$ & $\mathbf{7 8}(\mathbf{7 8 . 0 0})$ & $\mathbf{1 0 0}$ \\
\hline
\end{tabular}

Figures in parentheses indicate percentage of the individual category to the total of that category 
Table.3 Frequency distribution of the total farm women according to food insecurity status and scale

\begin{tabular}{|l|c|c|}
\hline \multicolumn{1}{|c|}{ Status } & Scale & Frequency \\
\hline Mild Food Insecure & Scale 2 & $\mathbf{2 6}(\mathbf{2 6 . 0 0 )}$ \\
\hline Moderate Food Insecure & Scale 3 & $\mathbf{4 5}(\mathbf{4 5 . 0 0 )}$ \\
\hline Severe Food Insecure & Scale 4 & $\mathbf{7 ( 7 . 0 0 )}$ \\
\hline
\end{tabular}

Figures in parentheses indicate percentage with respect to 100 sample farm women

Table.4 Frequency distribution of farm women in different category according to food security and insecurity status along with scale

\begin{tabular}{|l|c|c|c|c|}
\hline Particulars & Food secure & $\begin{array}{c}\text { Mild food } \\
\text { insecure }\end{array}$ & $\begin{array}{c}\text { Moderate food } \\
\text { insecure }\end{array}$ & $\begin{array}{c}\text { Severe food } \\
\text { insecurity }\end{array}$ \\
\hline $\begin{array}{c}\text { Category of } \\
\text { farmwomen }\end{array}$ & Scale 1 & Scale 2 & Scale 3 & Scale 4 \\
\hline Marginal & $2(9.09)$ & $\mathbf{7 ( 2 6 . 9 4 )}$ & $\mathbf{1 1}(\mathbf{2 4 . 4 4 )}$ & $\mathbf{2 ( 2 8 . 5 7 )}$ \\
\hline Small & $\mathbf{6 ( 2 7 . 2 7 )}$ & $\mathbf{1 3}(\mathbf{5 0 . 0 0})$ & $\mathbf{1 9}(42.22)$ & $\mathbf{5 ( 7 1 . 4 2 )}$ \\
\hline Medium & $\mathbf{1 4 ( 6 3 . 6 3 )}$ & $\mathbf{6 ( 2 3 . 0 7 )}$ & $\mathbf{1 5}(\mathbf{3 3 . 3 3})$ & Nil \\
\hline Total & $\mathbf{2 2 ( 1 0 0 )}$ & $\mathbf{2 6 ( 1 0 0 )}$ & $\mathbf{4 5}(\mathbf{1 0 0})$ & $\mathbf{7 ( 1 0 0 )}$ \\
\hline
\end{tabular}

Figure in parentheses indicate percentage of the individual category to the total of that category

Table.5 Regression coefficient of the independent factors i.e. age, education, land, agricultural income, non-agricultural income and expenditure on food per person per month in relation to Body Mass Index

\begin{tabular}{|l|l|c|c|c|}
\hline No. & \multicolumn{1}{|c|}{ Model } & $\begin{array}{c}\text { Standardized Coefficients } \\
\text { Beta }\end{array}$ & T & Significance \\
\hline $\mathbf{1}$ & (Constant) & 0.042 & & 0.000 \\
\hline $\mathbf{2}$ & Education & -0.280 & 9.761 & 0.429 \\
\hline $\mathbf{3}$ & Age & 0.447 & .795 & 0.000 \\
\hline $\mathbf{4}$ & $\begin{array}{l}\text { Expenditure on } \\
\text { food per person per } \\
\text { month }\end{array}$ & & -4.200 & 0.000 \\
\hline $\mathbf{5}$ & Agricultural income & 0.196 & & \\
\hline $\mathbf{6}$ & $\begin{array}{l}\text { Non-agricultural } \\
\text { income }\end{array}$ & 0.184 & 6.027 & 0.041 \\
\hline $\mathbf{7}$ & $\begin{array}{l}\text { Land holding } \\
\mathbf{8}\end{array}$ & 0.067 & 2.070 & 0.000 \\
\hline & $\mathbf{R}^{\mathbf{2}}$ & 0.78 & 3.710 & 0.468 \\
\hline
\end{tabular}

According to Table-5, the $\mathrm{R}^{2}$ value was calculated to be 0.783 which indicates that78.3 percent of the variation in Body Mass Index is explained by the independent variable taken under study and the rest of the variation is due to other variables which were not included in the model. Regression coefficient (bi) of different independent factors which shows the relative influence of the independent factors on the Body Mass 
Index is presented in Table-5. The result revealed that the regression coefficient for age turned out to be negative. The significant coefficient of age with negative sign indicates that a 1 percent increase in age (value term), would bring about a decrease in BMI by 0.28 percent.

The regression coefficients of landholding and education were found to be 0.067 and 0.042. The regression coefficient of agriculture income is positive with a value of 0.19 . It shows that a 1 percentage increase in agricultural income would bring an increase in BMI by 0.19 percent.

The regression coefficient of non-agricultural income is 0.18 . It implies that a 1 percentage increase in non-agricultural income would bring an increase in BMI by 0.18 percent in a significant manner. The regression coefficient of the expenditure on food per person per month is 0.44 .

It shows that a percentage increase in expenditure on food per person per month would bring an increase in BMI by 0.44 percent. Regression coefficient of the expenditure on food per person per month is more than the regression coefficient of agricultural and non-agricultural income in magnitude.

It implies that expenditure on food per person per month influences BMI more than that of agricultural and non-agricultural income in a significant manner. Majority (78 percent)of the respondents belong to food insecure category whereas 22 percent respondents are in food secure category. Further, results revealed that $90.91 \%$ percent of the farm women among marginal farmer's households fall in the insecure food category. Majority of sample farm women belong to moderate food insecure (45\%) followed by mild food insecure $(26 \%)$, and severe food insecure category $(7 \%)$. It shows the prevalence of food insecurity however, at a moderate level in the sample population and the majority belongs to the marginal farmers.

Assessment of the relative contribution of the independent factor i.e. age (years), education (years of schooling), landholding (Acres), expenditure on food per person per month (Rs.), agricultural and non-agricultural income (Rs.) on Body Mass Index $(\mathrm{Kg} / \mathrm{m} 2)$ shows that except for landholding and education other factors found to be significant. However, age has an indirect or negative effect on BMI. Expenditure on food per person per month is significant and the highest positive contributing/influencing factor to BMI even more than agricultural and non-agricultural income. The result shows that the $\mathrm{R}^{2}$ for the regression model is 0.783 which means that 78.3 percent of variation in Body Mass Index explained by the undertaken independent variables.

\section{References}

Devadarshini, C.(2015).Assessment of Poverty and Food Security among Women in Agricultural Sector- A Study in Coastal Odisha, Professor Jayashankar Telangana State Agricultural Hyderabad,D9931.

Food and Agriculture Organisation,(1996). Rome Declaration on World Food Security and World Food Summit Plan of Action. http://www.Food and Agriculture Organisation .org/DOCREP/003/W3613E/W3613E0 0.html.

Food and Agriculture Organisation,(1999). Gender and Statistics: Key Elements for the Advancement of Women, Rome Italy.

Food and Agriculture Organisation,(2004). State of Food Insecurity in the World, 
Rome, Italy. www.fao .org/docrep/.

Food and Agriculture Organisation.(2011).

Final Report: Evaluation of Food and Agriculture Organisation's Role and Work in Nutrition. Food and Agriculture Organisation, Office of Evaluation, MB663. 108th Programme Committee and UN Scaling Up Nutrition (SUN). Nutrition Security.

Food and Agriculture Organisation,(2013). The State of Food Insecurity in the World. The Multiple Dimensions of Food Security, Food and Agriculture organization of the United Nations.
Rome. http:www.fao.org/docrep/018 /i3434e.pdf.

International Fund for Agricultural Development.(2012). Brief Report. The future of World food and nutrition security. Http:/ www. ifad.org/ rural poverty portal.

Food and

Agriculture Organisation,(2018). The State of Food Insecurity in the World.The Multiple Dimensions of Food Security, Food and Agriculture Organization of the United Nations. Rome, http:www. fao.org/docrep/023/i544e.pdf.

\section{How to cite this article:}

Dinesh, H. P. Singh and Gyanaprakash Bishi. 2020. Assessment of Food Security among Farm Women - A Case Study of Mirzapur District in Uttar Pradesh, India. Int.J.Curr.Microbiol.App.Sci. 9(03): 1075-1081. doi: https://doi.org/10.20546/ijcmas.2020.903.126 